\title{
Slow-release amylase increases in vitro ruminal digestion of maize and sorghum grain
}

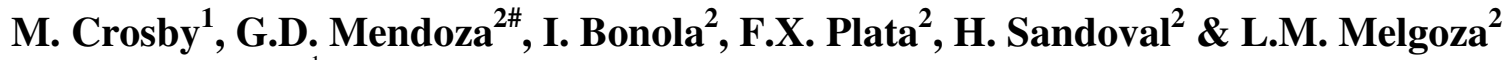 \\ ${ }^{1}$ Colegio de Postgraduados, Campus Montecillo, México 56230 \\ ${ }^{2}$ Universidad Autónoma Metropolitana, Unidad Xochimilco, 04960 México
}

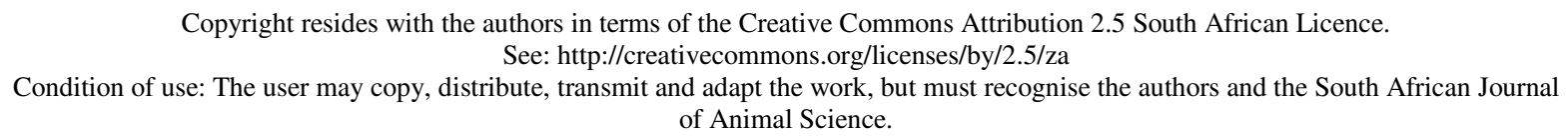

\begin{abstract}
The objective of this study was to evaluate the effects of slow-release $\alpha$-amylase in ruminal in vitro digestion of maize and sorghum grains. Digestibility was measured using an in vitro procedure with $40 \mathrm{~mL}$ of buffer and $10 \mathrm{~mL}$ of ruminal fluid, flushed with $\mathrm{CO}_{2}$ and incubated at $39{ }^{\circ} \mathrm{C}$. The digestibility of sorghum and maize grain was measured after 6 and 12 hours of fermentation with or without exogenous $\alpha$-amylase in powder form or dispersed in a matrix system for slow release by a diffusional mechanism. Tablets were used as the drug release matrix system, and were formulated with barium sulphate and ethylcellulose as the core of the final tablet. Treatments consisted of incubation of sorghum or maize grains with four doses of enzyme, using $\alpha$-amylase in powder or in the press-coated tablet (16 treatments). The results showed that with a higher dose of exogenous enzyme, the digestibility of the grains was improved. Sorghum and maize digestion with tablets were improved compared with $\alpha$-amylase in powder form. Releasing $\alpha$-amylase from matrix tablets represents a potential technology to improve grain digestion in ruminants.
\end{abstract}

Keywords: Enzymes, slow-release, grains, digestibility, rumen

\#Corresponding authors: gmendoza@correo.xoc.uam.mx

\section{Introduction}

The finishing of sheep can be carried out on high grain diets (Mendoza et al., 2007), where sorghum and maize are commonly used in the diet. However, both grains are usually processed to increase their digestibility (Ortega \& Mendoza, 2003). In vitro and in situ studies using these grains as substrates have shown that the addition of the enzyme, $\alpha$-amylase from Bacillus licheniformis, or glucoamylase from Aspergillus niger in liquid form, increases grain digestion as a function of dose (Gutierrez et al., 2005; Rojo et al., 2007).

Even when amylolytic enzymes have been shown to increase ruminal starch digestion, performance is not always improved (Rojo et al., 2005), because the addition of these enzymes increases the rate of starch digestion, causing subacute acidosis. Crosby et al. (2006) did not find a response in terms of gain, but observed a great variation in intake at different doses of glucoamylase in sheep. Therefore, modulation of the rate of starch digestion may be needed in systems based on grains to improve animal performance.

Controlled release tablets may be a potential technology to administer exogenous enzymes because these systems are formulated in the dry state, a stable form that can be released slowly (Melgoza et al., 2002). These kind of tablets can be designed to reduce the frequency of dosage because the polymer in the matrix increases the duration of the release process of the enzyme and can be designed to remain unalterable in ruminal fluid (Melgoza et al., 2007). Matrix tablets are a type of controlled drug delivery system that releases a drug in a continuous manner. These tablets are in solid dosage forms, containing one or more active ingredients, which are prepared by compression and may be left uncoated or coated with different polymers; they contain an inert nucleus or core, which modifies the release platform's density (Mathiowitz, 1999).

Ruminal drug delivery systems have been developed for ruminants to provide solutions to a variety of animal health problems and to promote growth and efficient metabolism. These include antihelminthic 
compounds, ionophores and minerals (Vandame \& Ellis, 2004). Slow-release systems have also been used for urea (Huntington et al., 2006), but information on incorporating enzymes into these formulations is scarce. Because of the potential benefits of reducing the rate of starch digestion in ruminants, the objective of the present study was to develop a press-coated tablet with a core of $\mathrm{BaSO}_{4}$ and ethylcellulose/ $\alpha$-amylase as the matrix system, with prolonged release in a ruminal in vitro system, using maize and sorghum as substrates, with the goal of improving grain digestion. The hypothesis of this study was that slowly providing exogenous amylases could improve grain digestion, compared with a powder formulation.

\section{Materials and Methods}

The materials used in the production of press-coated tablets were barium sulphate (synthesized in the laboratory); ethylcellulose (Dow Chemical Company, Midland, MI, USA) as the core of the final tablet and $\alpha$-amylase from Aspergillus niger (Nutrer S.A., Naucalpan, Edo. de Mexico, Mexico) as the matrix-forming polymer. Barium sulphate was obtained from the equimolar reaction between barium chloride and sulphuric acid. Both solutions were mixed, allowed to react until a white precipitate was formed, and then the phases were separated by decantation, and the precipitate was washed with water until the $\mathrm{pH}$ was neutral. Finally, the precipitate was dried in an oven (Riossa HS, Mexico) at $60{ }^{\circ} \mathrm{C}$, and the weight and yield were recorded.

Ethylcellulose (Ethocel std 100 premium Dow Chemical Company, Midland, MI, USA) was used to provide a porous and coherent structure in the matrix system. To determine the mean particle size, the powder was passed through normalized ASTM E-11 sieves with the following screens: 20, 30, 40, 50, 60, 70, 80 (0.178 and $0.853 \mathrm{~mm}$ ), using an electric sieve (Rotap Rx-29, Mentor, OH, USA) with continuous vibration for 15 minutes. The ethylcellulose was then ground and sieved again with 270 and 140 screens to select a granulometric fraction between 53 and $104 \mu \mathrm{m}$.

In order to characterize the $\alpha$-amylase from Aspergillus niger, three solutions were prepared with the enzyme powder $(150,250$ and $500 \mu \mathrm{g})$ and the amount of protein was quantified with a spectrophotometer (Varian Cary 100) at $750 \mathrm{~nm}$, using the Lowry's technique (1951). The enzymatic activity of the amylase was determined by measuring reducing sugars released by starch digestion with di-nitro-salicylic acid as the reagent on a Vary Cary 100 spectrophotometer at $550 \mathrm{~nm}$ (Dubois et al., 1956). The substrate was a $1 \%$ potato starch solution prepared at different $\mathrm{pH}$ at rumen temperature $\left(40{ }^{\circ} \mathrm{C}\right)$, containing $0.06 \% \mathrm{CaCl}_{2}$. The enzyme was incubated with a phosphate buffer $(100 \mathrm{mM})$ at $\mathrm{pH} 6.8$. The enzyme concentration was 42 $\mu \mathrm{g} / \mathrm{mL}$ and the incubation time with substrate was 15 minutes. The enzymatic units (micromoles of reducing sugars produced per minute) per milligram of protein (IU/mg) were determined.

The press-coated tablets were prepared in two steps. First, cores of barium sulphate were designed to be $740 \mathrm{mg}$ in weight, $7 \mathrm{~mm}$ in diameter and with a density above $3 \mathrm{~g} / \mathrm{mL}$ by direct compaction in a rotary tablet machine (Riva piccola B/10, Ciudadela-BS.AS, Argentina). In the second step, the matrix systems were elaborated with amylase, Ethocel std 100 premium and barium sulphate in the proportion $30: 60: 10$. Barium sulphate was passed through a screen $30(0.599 \mathrm{~mm})$, but the enzyme was not sieved. The core or "sinker" was placed in the centre of the matrix system. Tablets were produced by direct compression at 1500 psi in a hydraulic press (Carver C, Wabash, IN, USA). The weight of the final tablets (press-coated tablets) was $1.2 \mathrm{~g}$ with a diameter of $10 \mathrm{~mm}$.

The hardness of six press-coated tablets was measured with a hardness tester (Vankel 2000, Cary, N.C., USA), and friability (property related to tablet hardness) was tested with the equivalent of $6 \mathrm{~g}$ of tablets in a friabilator (Elecsa FE30, Mexico) for $4 \mathrm{~min}$ at $25 \mathrm{rpm}$. Enzyme release from the press-coated tablets was performed in vitro, using a dissolutor (Hanson Research 72RL, Chatsworth, CA, USA), employing apparatus 2 (USP 32) for 26 hours. The dissolution medium was $500 \mathrm{~mL}$ of $\mathrm{NaCl}(0.85 \%)$ at $39 \pm 0.5{ }^{\circ} \mathrm{C}$ and $50 \mathrm{rpm}$. The amount of enzyme released was quantified by the Lowry method (1951) and the enzymatic activity was assessed by the release of reducing sugars with the DNS reactive and potato starch as the substrate dissolved in phosphate buffer with pH 6 at $40{ }^{\circ} \mathrm{C}$ (Dubois et al., 1956). All analyses were done in triplicate. The release data was analyzed using the first-order Higuchi model to determine the mechanism of drug release from the matrices (Higuchi, 1963).

Digestibility was measured with the in vitro procedure of Tilley \& Terry (1963), modified for grains with $40 \mathrm{~mL}$ of buffer and $10 \mathrm{~mL}$ of ruminal fluid, flushed with $\mathrm{CO}_{2}$ and incubated at $39{ }^{\circ} \mathrm{C}$ (Mendoza et al., 1995). Incubation was replicated three times. The ruminal inoculum was collected from a Holstein steer (450 $\mathrm{kg}$ of BW), fitted with a ruminal cannula, which was fed a diet consisting of forage (lucerne hay, maize silage) and concentrate (sorghum grain, soybean meal, cane molasses) in a 50:50 ratio. Samples of maize 
and sorghum were incubated with different doses of $\alpha$-amylase. Fermentation was carried out for 6 and 12 hours to determine in vitro grain digestibility (Mendoza et al., 1995). The sorghum and maize grains were ground in a Thomas Willey model 4 mill (Philadelphia, USA) and passed through a mesh with an opening of $1 \mathrm{~mm}$. Three incubations were conducted with 16 treatments, and each treatment was incubated in triplicate, using $\alpha$-amylase in powder and dispersed in the matrix system of the press-coated tablets. The $\alpha$-amylase in powder was incubated in digestibility tubes at doses of 150,300 and $450 \mathrm{mg}$, equivalent to the amount of enzyme in one, two and three tablets, respectively, with $500 \mathrm{mg}$ of maize or sorghum grains, $40 \mathrm{~mL}$ of McDougall's buffer, and $10 \mathrm{~mL}$ of ruminal liquid, and flushed with $\mathrm{CO}_{2}$. Fermentation was stopped by freezing. Digestibility data were analyzed with a completely randomized block design with incubation as the blocking criteria, using the GLM procedure of SAS (1996). The effects of the addition of the enzyme as a powder versus the matrix system on digestibility were compared by orthogonal contrasts within doses for both grains. The linear and quadratic effects of the dose of amylase in powder or in the matrix system were tested (SAS, 2002).

\section{Results and Discussion}

The average hardness of six press-coated tablets was $15.45 \mathrm{kp}$. The enzymatic activity at $\mathrm{pH} 6.8$ was $1.41 \pm 0.21 \mathrm{IU} / \mathrm{mg}$ protein. This amylase has shown activity under ruminal conditions (Gutierrez et al., 2005; Rojo et al., 2005). The dissolution test showed that the enzyme was released slowly by the tablet, with a percentage of enzyme release of $63.7 \%$ at 12 hours and $77.3 \%$ at 24 hours. Higuchi's model (1963) confirmed diffusional release $(\mathrm{r}=0.98)$, which could help to prevent the inactivation of the enzyme by rumen proteases, and also reduce the potential problem of acidosis.

Although barium is considered a heavy metal and a dangerous toxin, barium sulphate is less soluble, making it nominally safer and practically non-absorbable by organisms that ingest it. In fact, this compound has been used as a faecal marker (Figueroa et al., 1968). Its possible use as an additive in feed for ruminants raises the possibility of considering the potential of pollution of the environment. However, there are no environmental regulations for the use of barium sulphate, and the Texas Commission on Environmental Quality recently confirmed that the insoluble barium compound barium sulphate is not of concern in human health, thereby eliminating the need for clean-up standards or site remediation for this compound (McGinty et al., 2007).

Increasing the amylase dose linearly increased the digestibility of sorghum and maize $(P<0.01)$ at 6 and 12 hours, independent of the powder versus matrix formulation (Tables 2 and 3). Grain digestion was improved when the enzyme was administrated in a matrix tablet, compared with the powder $(52.6 \% \mathrm{vs}$. $45.9 \%, P<0.01)$. Our hypothesis was that the enzyme powder would promote a rapid release of glucose from grains, which acidifies the $\mathrm{pH}$ and inhibits the action of amylolytic bacteria. This explains why increases in

Table 1 Effect of $\alpha$-amylase in powder or dispersed into a matrix system and dose on in vitro dry matter digestibility of maize and sorghum after 6 hours of incubation

\begin{tabular}{lcccc}
\hline \multirow{2}{*}{ Dose, mg } & \multicolumn{2}{c}{ Maize $^{2}$} & \multicolumn{2}{c}{ Sorghum $^{2}$} \\
\cline { 2 - 5 } & Powder & Matrix system & Powder & Matrix system \\
\hline 0 & $31.27^{\mathrm{b}} \pm 2.30$ & $28.46^{\mathrm{b}} \pm 3.76$ & $23.50^{\mathrm{a}} \pm 2.90$ & $23.45^{\mathrm{c}} \pm 2.24$ \\
150 & $33.17^{\mathrm{b}} \pm 2.82$ & $36.61^{\mathrm{a}} \pm 3.84$ & $31.27^{\mathrm{a}} \pm 0.54$ & $38.67^{\mathrm{b}} \pm 5.41$ \\
300 & $38.45^{\mathrm{a}} \pm 1.64$ & $38.76^{\mathrm{a}} \pm 4.67$ & $32.39^{\mathrm{a}} \pm 2.12$ & $41.87^{\mathrm{a}} \pm 3.47$ \\
450 & $38.12^{\mathrm{a}} \pm 1.41$ & $38.45^{\mathrm{a}} \pm 3.20$ & $33.31^{\mathrm{a}} \pm 1.26$ & $43.09^{\mathrm{a}} \pm 4.85$ \\
Linear $^{1}$ & 0.0001 & 0.0001 & 0.02 & 0.001 \\
Quadratic $^{1}$ & 0.09 & 0.003 & 0.21 & 0.001 \\
& & & & \\
\hline
\end{tabular}

\footnotetext{
${ }^{1}$ Probability of a significant effect of enzyme dose (linear or quadratic effect).

${ }^{2}$ The difference between the digestibility of the powder $v s$. the matrix system was different $(P<0.001)$ within doses (150, 300 and $450 \mathrm{mg}$ ) for both grains.

${ }^{\mathrm{abc}}$ Means with different superscript within columns differ $(P<0.05)$.
} 
Table 2 Effect of $\alpha$-amylase in powder or dispersed into a matrix system and dose on in vitro dry matter digestibility of maize and sorghum after 12 hours of incubation

\begin{tabular}{lcccc}
\hline \multirow{2}{*}{ Dose, mg } & \multicolumn{2}{c}{ Maize $^{2}$} & \multicolumn{2}{c}{ Sorghum $^{2}$} \\
\cline { 2 - 5 } & Powder & Matrix system & Powder & Matrix system \\
\hline 0 & $40.57^{\mathrm{d}} \pm 3.76$ & $39.22^{\mathrm{c}} \pm 3.55$ & $36.84^{\mathrm{b}} \pm 2.30$ & $34.67^{\mathrm{b}} \pm 3.76$ \\
150 & $55.40^{\mathrm{c}} \pm 1.72$ & $62.47^{\mathrm{b}} \pm 3.84$ & $52.53^{\mathrm{a}} \pm 3.84$ & $62.88^{\mathrm{a}} \pm 2.72$ \\
300 & $58.09^{\mathrm{b}} \pm 4.67$ & $67.09^{\mathrm{a}} \pm 3.93$ & $55.81^{\mathrm{a}} \pm 1.64$ & $64.54^{\mathrm{a}} \pm 4.67$ \\
450 & $63.99^{\mathrm{a}} \pm 3.20$ & $70.06^{\mathrm{a}} \pm 2.96$ & $58.73^{\mathrm{a}} \pm 1.41$ & $66.24^{\mathrm{a}} \pm 3.20$ \\
Linear $^{1}$ & 0.0001 & 0.0001 & 0.0001 & 0.0001 \\
Quadratic $^{1}$ & 0.0001 & 0.0001 & 0.0001 & 0.001 \\
& & & & \\
\hline
\end{tabular}

\footnotetext{
${ }^{1}$ Probability of a significant effect of enzyme dose (linear or quadratic effect).

${ }^{2}$ The difference between the digestibility of the powder $v s$. the matrix system was different $(P<0.001)$ within doses $(150,300$ and $450 \mathrm{mg})$ for both grains.

${ }^{\text {abc }}$ Means with different superscript within columns differ $(P<0.05)$.
}

digestibility are highest when the enzyme was supplied slowly by the tablet formulation. It has been demonstrated that a high glucose concentration in the environment inhibits amylolytic activity (Cotta, 1988). In this experiment, the tablet released the enzyme slowly and may avoid the suppression of ruminal bacteria and the increase in acidity, promoting greater digestibility of starch. Even though this was an in vitro assay, it is possible to expect additional benefits in vivo by reducing the rate of starch digestion with this technology compared with technology where the enzyme is released rapidly (Mendoza et al., 2000).

Controlled release systems could also reduce the degradation of amylolytic enzymes by ruminal microbes. Rojo et al. (2005) evaluated the half-life of exogenous amylolytic enzymes in ruminal conditions and found values between 4 and 6 hours, which could explain the positive effects on grain digestion observed with tablets versus powder. The optimum $\mathrm{pH}$ for the action of exogenous amylase is between 5.8 and 6.6 and in a temperature range between 70 and $72{ }^{\circ} \mathrm{C}(\mathrm{Naz}, 2002)$. Therefore, the physiological conditions of the rumen in a grain-based diet meet the $\mathrm{pH}$, but not the temperature requirements. However, the amylase activity of Aspergillus niger is so high that it may have a synergistic effect on the digestion of grains. Enzyme tablet design is a challenge for ruminant nutrition because the conditions for a ruminal device that will remain in the reticulum or the front part of the rumino-reticulum for extended periods requires a specific density to disperse the pharmacologically inactive excipient (the matrix) and the proper physical and chemical properties to control the slow release of the drug. A ruminal device must function in different conditions of the rumen environment, such as changes in $\mathrm{pH}$, motility and abrasion, as well as enzymatic and bacterial activity (Vandame \& Ellis, 2004), which require further evaluation.

It was interesting to observe that after $12 \mathrm{~h}$ of incubation, the addition of amylase in tablet form at the highest dose with sorghum resulted in similar digestion to that of maize (Table 2). This is important, considering that grains with a poor ruminal digestion such as sorghum have less energy than maize (Ortega \& Mendoza, 2003) and may require higher doses of the enzyme if there is enough potentially digestible starch in the rumen.

\section{Conclusions}

The use of $\alpha$-amylase from Aspergillus niger as an exogenous enzyme increased in vitro sorghum and maize grain digestion. Its effect was improved when the enzyme was administered slowly from tablets. Further research is needed to evaluate this formulation in vivo and to assess the possibilities of using slowrelease enzymes under practical feeding conditions.

\section{Acknowledgements}

The authors are grateful for the donation of $\alpha$-amylase and ethylcellulose from Nutrer S.A. and Laboratory Colorcon de Mexico S. de R.L. de C.V., respectively. 


\section{References}

Cotta, M.R., 1988. Amylolytic activity of selected of ruminal bacteria. Appl. Environ. Microbiol. 54, $772-776$.

Crosby, M.M., Mendoza, G.D., Melgoza, L.M., Bárcena, R., Plata, F.X. \& Aranda, E.M., 2006. Effects of Bacillus licheniformis amylase on starch digestibility and performance. J. Appl. Anim. Res. 30, 133-136.

Dubois, M., Gilles, K.A., Hamilton, J.K., Rebers, P.A. \& Smith, F., 1956. Colorimetric Method for determination of sugars and related substances. Anal. Chem. 28, 350-356.

Figueroa, W.G., Jordan, T. \& Bassett, S., 1968. Use of barium sulphate as an unabsorbable fecal marker. Am. J. Cl. Nutr. 11, 1239-1245.

Gutierrez, C., Mendoza, G.D., Ricalde, R., Melgoza, L.M. \& Plata, F., 2005. Effect of exogenous amylase or glucoamylase dose on in situ ruminal digestion of corn and sorghum. J. Appl. Anim. Res. 27, 7-10.

Higuchi, T., 1963. Mechanism of sustained-action medication. Theoretical analysis of rate of release of solid drugs dispersed in solid matrices, J. Pharm. Sci. 52, 1145-1149.

Huntington, G.B., Harmon, D.L., Kristensen, N.B., Hanson, K.C. \& Spears, J.W., 2006. Effects of a slow release urea source on absorption of ammonia and endogenous production of urea by cattle. Anim. Feed Sci. Technol. 130, 225-241.

Lowry, O., Rosebrough, N. \& Lewis, F., 1951. Protein measurement with the folin phenol reagent, J. Biol. Chem. 193, 265-275.

Mathiowitz, E., 1999. Encyclopedia of Controlled Drug Delivery, John Wiley \& Sons, New York.

McGinty, J., McHugh, T.E. \& Higgins, E.A., 2007. Barium sulfate: a protocol for determining higher sitespecific barium cleanup levels. E\&P Environmental and Safety Conference, 5-7 March 2007, Galveston, Texas, U.S.A. 7. Society of Petroleum Engineers. SPE 106802. pp.1-6.

Melgoza, L.M., Contreras, L., Rodríguez, S. \& González, M., 2002. Matrix systems of controlled release. Rev. Mex. Cienc. Farm. 33, 58-67. (in Spanish, English abstract).

Melgoza, L.M., Rocha, A., Plata, F., Mendoza, G.D. \& Sandoval, H., 2007. Film coating of compressed matrix with high density and pellets for the modified release of urea in ruminants. Rev. Mex. Cienc. Farm. 38, 15-23. (in Spanish, English abstract).

Mendoza, M.G.D., Britton, R.A. \& Stock, R.A., 1995. Effect of protozoa and urea level on in vitro starch disappearance and amylolytic activity of ruminal microorganisms. Anim. Feed Sci. Technol. 54, 315-325.

Mendoza, G.D., Ortega, M.E., Ricalde, R. \& Martínez, J.A., 2000. Mathematical models to evaluate in vitro rate of starch digestion. Téc. Pec. Méx. 38, 51-65. (in Spanish, English abstract).

Mendoza, M.G.D., Plata, P.F., Ramírez, M.M, Mejia, D.M.A., Lee, R.H. \& Bárcena, G.R., 2007. Evaluation of complete feeds for intensive fattening of sheep. Rev. Cient. FCV-LUZ 15, 66-72. (in Spanish, English abstract).

Naz, S., 2002. Amylolytic enzymes. In: Enzymes and Food. Oxford University Press. pp. 110-113.

Ortega, M.E. \& Mendoza, G.D., 2003. Starch digestion and glucose metabolism in the ruminant: A review. Interciencia 28, 380-386.

Rojo, R., Mendoza, G.D., González, S., Landois, L., Garcia, R. \& Crosby, M.M., 2005. Effects of exogenous amylases from Bacillus licheniformis and Aspergillus niger on ruminal starch digestion and lamb performance. Anim. Feed Sci. Technol. 123, 655-665.

Rojo, R.R., Mendoza, G.D., Plata, F.X.P., Lara, B.A. \& Barcena, G.R., 2007. Comparison of methods of application on the effects of amylolytic enzymes on in vitro ruminal starch digestion. J. Appl. Anim. Res. 32, 81-84.

SAS, 2002. Statistical Analysis Systems user's guide Version 9.0.0.380. SAS Institute Inc., Raleigh, North Carolina, USA.

Tilley, M.A. \& Terry, R.A., 1963. A two-stage technique for the in vitro digestion of forage crops. J. Br. Grassld. Soc. 18, 104-109.

Vandame, Th F. \& Ellis, K.J., 2004. Issues and challenges in developing ruminal drug delivery systems. Adv. Drug Deliv. Rev. 56, 1415-1436. 